\title{
BEST PRACTICES
}

\section{Engineering Controls, Work Practices, and Exposure Monitoring for Occupational Exposures to Diacetyl and 2,3-Pentanedione}
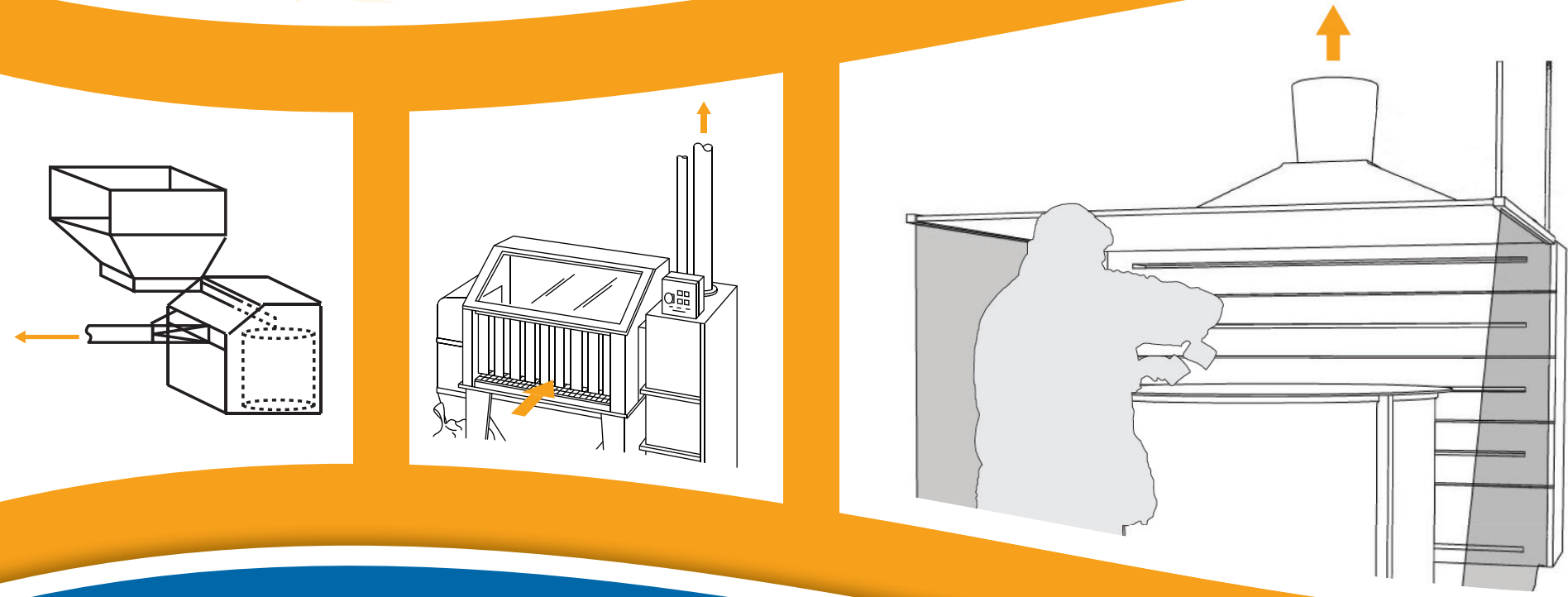

DEPARTMENT OF HEALTH AND HUMAN SERVICES

Centers for Disease Control and Prevention

National Institute for Occupational Safety and Health 



\section{BEST PRACTICES}

Engineering Controls, Work Practices, and

Exposure Monitoring for Occupational Exposures

to Diacetyl and 2,3-Pentanedione

By Kevin H. Dunn, Lauralynn Taylor McKernan, and Alberto Garcia

DEPARTMENT OF HEALTH AND HUMAN SERVICES

Centers for Disease Control and Prevention

National Institute for Occupational Safety and Health 


\section{This document is in the public domain and may be freely copied or reprinted.}

\section{DISCLAIMER}

Mention of any company or product does not constitute endorsement by the National Institute for Occupational Safety and Health (NIOSH). In addition, citations to websites external to NIOSH do not constitute NIOSH endorsement of the sponsoring organizations or their programs or products. Furthermore, NIOSH is not responsible for the content of these websites. All Web addresses referenced in this document were accessible as of the publication date.

\section{ORDERING INFORMATION}

To receive documents or other information about occupational safety and health topics, contact NIOSH:

Telephone: 1-800-CDC-INFO (1-800-232-4636)

TTY: 1-888-232-6348

CDC INFO: www.cdc.gov/info

or visit the NIOSH website at www.cdc.gov/niosh.

For a monthly update on news at NIOSH, subscribe to NIOSH eNews by visiting www.cdc.gov/niosh/eNews.

\section{SUGGESTED CITATION}

NIOSH [2015]. Best practices: engineering controls, work practices and exposure monitoring for occupational exposures to diacetyl and 2,3-pentanedione. By Dunn KH, McKernan LT, Garcia A. Cincinnati, OH: U.S. Department of Health and Human Services, Centers for Disease Control and Prevention, National Institute for Occupational Safety and Health, DHHS (NIOSH) Publication 2015-197.

DHHS (NIOSH) Publication No. 2015-197

July 2015

\section{SAFER • HEALTHIER • PEOPLE ${ }^{\text {TM }}$}




\section{ACKNOWLEDGMENTS}

The principal contributors to this publication were Kevin H. Dunn and Alberto Garcia, Division of Applied Research and Technology; Lauralynn Taylor McKernan, Laura Hodson, Todd Niemeier, Vanessa B. Williams, Gino Fazio, Ellen Galloway, and Rachel Thieman, Education and Information Division; James Couch, Division of Surveillance, Hazard Evaluations and Field Studies; Richard Kanwal, John Whalen, Edward Burroughs (under contract to the National Institute for Occupational Safety and Health); and Greg Kullman, Division of Respiratory Disease Studies.

Prior to publication this document was reviewed by Kay Kreiss, Division of Respiratory Disease Studies. Technical expertise was provided by Ann Hubbs, Health Effects Laboratory Division; and Jay Parker, National Personal Protective Technology Laboratory. This document was also externally peer reviewed by Kelly Howard, California Occupational Safety and Health Administration (Cal/OSHA); and Gerry Lanham, KBD Technic. 
This page intentionally left blank 


\section{CONTENTS}

DESCRIPTION OF EXPOSURE AND HEALTH EFFECTS. ............ 1 ENVIRONMENTAL MONITORING FOR DIACETYL AND

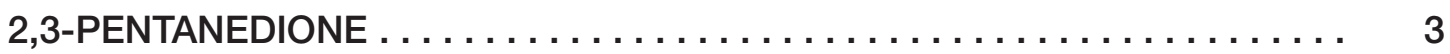

Sampling and Analysis for Diacetyl Vapor .......................... 3

Sampling and Analysis for 2,3-Pentanedione Vapor.................. 4

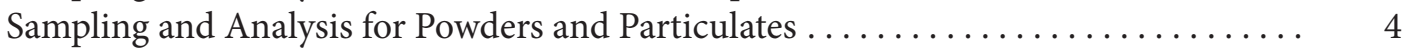

Real-time or Near Real-time Techniques for Diacetyl and 2,3-Pentanedione. ....... 4

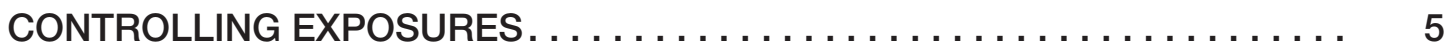

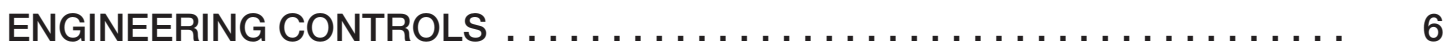

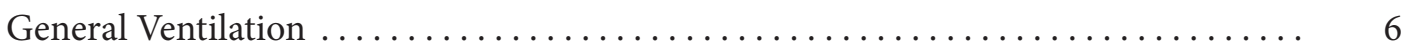

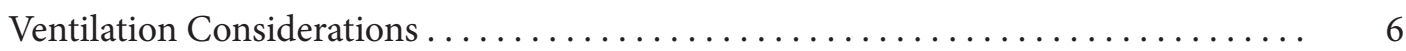

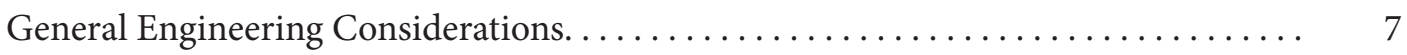

Small-Scale Weighing and Handling of Flavoring Ingredients $\ldots \ldots \ldots \ldots \ldots \ldots \ldots$

Filling, Mixing, and Emptying of Large Mixing Tanks . . . . . . . . . . . . 8

Dumping of Powdered Ingredients into a Blender (Bag Dumping) ............ 9

Discharging of Powdered Flavoring from a Blender/Spray Dryer (Bag Filling) ...... 9

ADMINISTRATIVE AND WORK PRACTICE CONTROLS . . . . . . . . . . . 10

PERSONAL PROTECTIVE EQUIPMENT. . . . . . . . . . . . . . 11

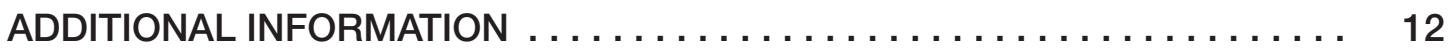

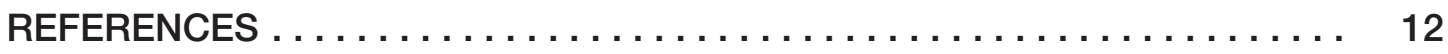

\section{LIST OF FIGURES}

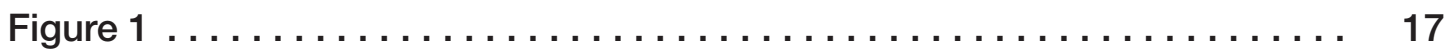

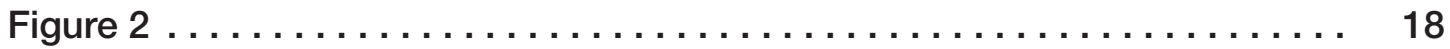

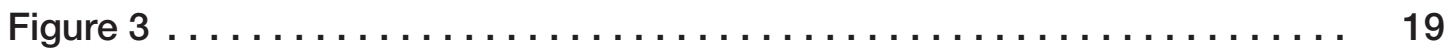

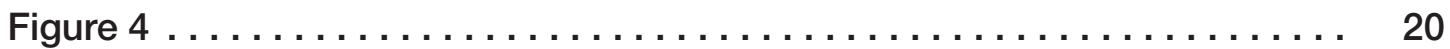

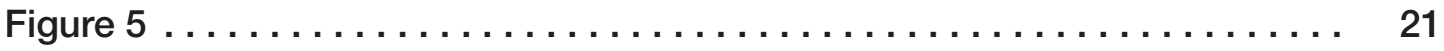

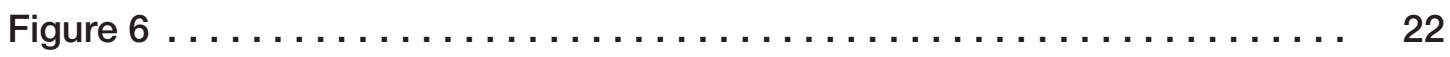

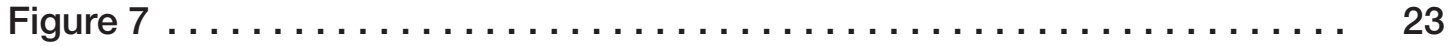

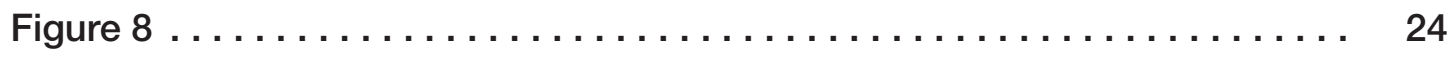

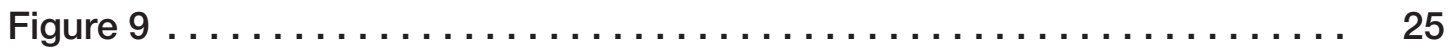

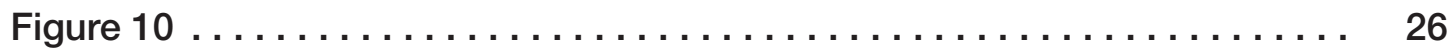

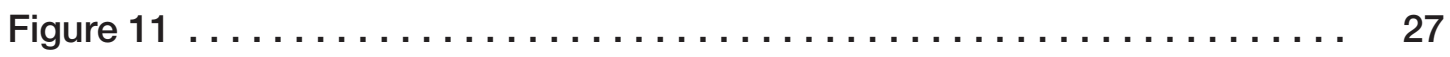

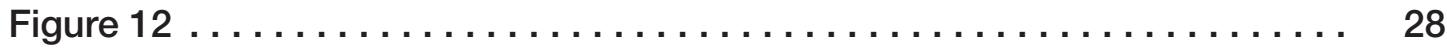



Workers who handle diacetyl or work in areas where diacetyl exposure occurs are at risk of developing severe lung disease if their exposures are not properly controlled. The National Institute for Occupational Safety and Health (NIOSH) has developed guidance in a variety of areas to reduce workers' exposures to diacetyl through engineering controls, best work practices, and techniques for monitoring airborne diacetyl exposures. Although these guidelines emphasize diacetyl, they can be applied to reduce exposures to diacetyl substitutes such as 2,3-pentanedione and other alpha-diketones.

\section{DESCRIPTION OF EXPOSURE AND HEALTH EFFECTS}

Flavorings are substances that alter or enhance the taste of food. They are composed of various natural and manmade chemicals and may consist of a single chemical, but more often they are complex mixtures. Workers in the flavorings production industry may be exposed to these substances in the form of solids, liquids, or vapors. Although thousands of flavoring ingredients are in use, little is known about most of these in terms of worker health effects, and few have occupational exposure guidelines such as recommended exposure limits (REL), permissible exposure limits (PEL), or threshold limit values (TLV) ${ }^{\circledR}$.

NIOSH investigations have found that workplace exposure to diacetyl can result in reduced lung function and also cause a severe lung disease known as obliterative bronchiolitis. In obliterative bronchiolitis, inflammation and scarring occur in the smallest airways of the lung and can lead to severe and disabling shortness of breath. Symptoms include cough and shortness of breath on exertion. Obliterative bronchiolitis is an irreversible lung disease whose symptoms typically do not improve when the worker goes home at the end of the workday, on weekends, or on vacations. Obliterative bronchiolitis can reduce lung function enough to cause disability.

Occurrences of obliterative bronchiolitis were observed in the microwave popcorn industry in 2000 when eight workers were diagnosed with the disease after exposure to vapors from artificial butter flavoring ingredients including diacetyl [Akpinar-Elci et al. 2004a; Kreiss et al. 2002]. Several workers in flavoring manufacturing facilities were also diagnosed with obliterative bronchiolitis or severe fixed obstructive lung disease [CDC 2007]. Studies in four microwave popcorn plants found that a history of working as a mixer and higher cumulative exposure to diacetyl were associated with decreased lung function [Lockey et al. 2009]. In one 
flavoring manufacturing plant, nearly one third of workers had restrictive breathing abnormalities [NIOSH 2011a]. This suggests that workers exposed to diacetyl and other flavoring ingredients could potentially develop a range of occupational lung diseases.

More recently, facilities have begun producing or working with substitutes for diacetyl, such as 2,3-pentanedione [Day et al. 2011; Boylstein 2012]. 2,3-Pentanedione, a 5-carbon alphadiketone, is chemically very similar to diacetyl, a 4-carbon alpha-diketone. Reports on the toxicity of 2,3-pentanedione were first published in abstract form in 2010 [Hubbs et al. 2010; Morgan et al. 2010]. Acute inhalation exposures to 2,3-pentanedione cause airway epithelial damage that is similar to diacetyl in laboratory studies [Hubbs et al. 2012]. In 2-week inhalation studies in rats, 2,3-pentanedione caused proliferation of fibrous connective tissue in the walls of airways, and projections of fibrous connective tissue sometimes extended into the air passageways [Morgan et al. 2012a,b]. Preliminary data suggest that repeated exposures to either 2,3-pentanedione or diacetyl can cause airway fibrosis in rats [Morgan et al. 2012a]. In the acute inhalation study of 2,3-pentanedione, changes in gene expression were noted in the brain [Hubbs et al. 2012]. As a group, these results raise concerns that the toxicologic effects of diacetyl may be shared with other alpha-diketones, which are close structural analogs. Additional alpha-diketones of interest include but are not limited to those used in food manufacturing such as 2,3-hexanedione and 2,3-heptanedione. Diacetyl substitutes should not be assumed to be safe until toxicology studies are performed.

It is difficult to quantify the number of employees involved with flavor manufacturing and, more specifically, those who have diacetyl or diacetyl substitute exposure in the United States. According to the Environmental Protection Agency Non-Confidential Inventory Updating Report, diacetyl had an aggregate production volume between 10,000 and 500,000 pounds in 2002 [EPA 2002]. The North American Industry Classification System (NAICS) category 311, the most relevant category, includes subcategories Flavoring Syrup and Concentrate Manufacturing (NAICS Code 311930), Spice and Extract Manufacturing (NAICS Code 311942) and All Other Miscellaneous Food Manufacturing (NAICS Code 311999). In 2002, 21,000 workers were employed in facilities classified under 311930 and 311942 [Department of Commerce 2004]. According to the Flavor Extract Manufacturers Association, whose members account for approximately $95 \%$ of all flavors produced in the United States, a total of 6,520 employees work directly in the flavor manufacturing or laboratory activities in membership companies [Hallagan 2010]. In addition to workers who were exposed to diacetyl during its production or addition to flavored substances, health effects have also been observed in workers with downstream exposure to diacetyl from those flavored substances, including workers in areas such as quality control and packaging products within microwave popcorn facilities [Kanwal et al. 2006].

In 2010, California promulgated a regulation for occupational exposure to food flavorings containing diacetyl that requires installation of exposure controls to reduce exposures to the lowest feasible levels. In 2012, the American Conference for Governmental Industrial Hygienists published a threshold limit value ${ }^{\circledast}$ of 0.010 parts per million (ppm) $8 \mathrm{hr}$-time weighted average (TWA) with a short-term exposure limit (STEL) of $0.020 \mathrm{ppm}$ for diacetyl [ACGIH 2012]. NIOSH published its draft recommended exposure limits for diacetyl (5 parts per billion [ppb] 8hr-TWA, $25 \mathrm{ppb}$ STEL) and 2,3-pentanedione (9.3 ppb 8-hr TWA, $31 \mathrm{ppb}$ STEL) in August 2011 [NIOSH 2011b]. 


\section{ENVIRONMENTAL MONITORING FOR DIACETYL AND 2,3-PENTANEDIONE}

Measuring workers' exposures to diacetyl or 2,3-pentanedione may help: (1) identify processes, locations, or tasks with exposures of concern; (2) guide corrective actions such as engineering controls; (3) identify improved work practices; and (4) select appropriate respiratory protection. Diacetyl and 2,3-pentanedione are monitored using personal and area air samples because the predominant route of exposure is inhalation. Studies conducted by NIOSH researchers [NIOSH 2008a,b,c] and Martyny et al. [Martyny et al. 2008] describe common tasks performed by workers in the production of flavorings. Results of these surveys illustrate how sampling can identify emission sources and guide corrective actions.

Personal breathing zone sampling is the preferred method for estimating the exposure of a worker. To collect a breathing zone sample, the Occupational Safety and Health Administration (OSHA) states that the air sampling collection media be attached "to the shirt collar or as close as practical to the nose and mouth of the employee's breathing zone" [OSHA 2008a]. For personal sampling, a worker is outfitted with the air sampling equipment, and the inlet to the collection media is positioned within the worker's breathing zone. Area sampling can be performed for several purposes such as to evaluate exposure characteristics associated with a work area or process or to determine the efficacy of control systems. While the same sampling equipment and analytical procedures may be used in some cases for personal and area sampling, area sample results represent air concentrations at a fixed location. In contrast, personal sample results represent worker exposure averaged over the selected sampling period. The development of a comprehensive sampling strategy to assure selection of representative employees, appropriate work areas and proper sampling periods (time-weighted average vs short-term exposure limit sampling, etc.) should be done in consultation with a qualified professional. Sampling for diacetyl and 2,3-pentanedione as a vapor and a particulate (when present) should be considered because these compounds may be found in both phases.

\section{SAMPLING AND ANALYSIS FOR DIACETYL VAPOR}

Chemists at NIOSH and OSHA have developed a variety of sampling and analytical methods for determining concentrations of airborne diacetyl vapor. Selection of a method to use in any given situation should be made after consultation with an analytical laboratory accredited by the American Industrial Hygiene Association for analyses. Only qualified professionals should collect samples.

OSHA Method 1013 can be used simultaneously for diacetyl and acetoin [OSHA 2008b]. Samples are collected through two $600 \mathrm{mg}$ tubes that contain specially cleaned and dried silica gel in series at $0.05 \mathrm{~L} / \mathrm{min}$ for 180 minutes for a time-weighted average (TWA) concentration or $0.2 \mathrm{~L} / \mathrm{min}$ for 15 minutes for short-term concentration. Samples are extracted with an ethanol solution and analyzed by GC-FID.

OSHA Method 1012 is more sensitive and can also be used to analyze for diacetyl and acetoin for either a 180-minute or 15-minute sample [OSHA 2008c]. OSHA Method 1012 utilizes the same sample collection media and conditions as OSHA Method 1013. Prior to analysis, the extract is derivatized and analyzed by gas chromatography with electron capture detection to produce a tenfold increase in sensitivity. 


\section{SAMPLING AND ANALYSIS FOR 2,3-PENTANEDIONE VAPOR}

OSHA Method 1016 can be used to measure 2,3-pentanedione concentrations [OSHA 2010]. Samples are collected through two $600 \mathrm{mg}$ tubes containing specially cleaned and dried silica gel in series at $0.05 \mathrm{~L} / \mathrm{min}$ for 200 minutes for a TWA concentration or $0.2 \mathrm{~L} / \mathrm{min}$ for 15 minutes for short-term concentration. Samples are extracted with ethyl alcohol:water solution and analyzed by GC-FID.

\section{SAMPLING AND ANALYSIS FOR POWDERS AND PARTICULATES}

Sampling and analytical methods are available to quantify airborne particulate concentrations in the inhalable, thoracic, and/or respirable size ranges, but these methods are not specific for diacetyl or 2,3-pentanedione content. Measurement of airborne dust particles according to their size (e.g. inhalable, thoracic, and respirable) can help to inform where they may deposit in the respiratory tract. Several types of sampling devices are available (e.g., inhalable dust samplers, impactors, cyclones, and sampling cassettes) to provide measurements of different size fractions of airborne dust. In most cases, dust is collected onto a filter, and the filter can be analyzed gravimetrically to provide the mass of the dust. Validated methods such as NIOSH Method 0500 for total dust and NIOSH Method 0600 for respirable dust are available for the collection and gravimetric analysis of airborne dust [NIOSH 2012]. The collection filters should be hydrophobic (e.g., polyvinyl chloride) to minimize collection of moisture. Because of their toxicity, when a dust contains diacetyl and 2,3-pentanedione the results from this method should not be compared with nuisance dust occupational exposure limits alone. Gravimetric results can be useful qualitatively to identify job functions or tasks where corrective action may be needed.

\section{REAL-TIME OR NEAR REAL-TIME TECHNIQUES FOR DIACETYL AND 2,3-PENTANEDIONE}

Several analytical methods can provide real-time or near real-time results of volatile compounds such as diacetyl and 2,3-pentanedione. These methods have the unique advantage to provide exposure information in real time to identify emission sources and tasks associated with exposure. Each of these on-site techniques requires specialized equipment and expertise in its use.

Fourier transform infrared spectroscopy can be used to analyze a sample of gaseous molecules for chemical composition and for the concentration of individual chemical constituents. In this analysis, chemical functional groups absorb infrared radiation at specific, unique frequencies producing a characteristic spectrum of absorbed versus transmitted radiation. From this spectrum, identification and quantification of the gas is possible.

Photoionization detectors (PID) can be used to monitor air contaminant concentrations in industrial work environments, including flavoring manufacturing facilities. Photoionization analysis has become a favored technique for on-site monitoring of volatile organic compounds because of ease of operation, reliability, versatility, cost, and response to a wide variety of substances. PIDs respond to a broad range of volatile compounds (including diacetyl and 2,3-pentanedione) but do not provide concentrations specific to any particular compound. PIDs are often useful for process evaluation, identifying sources, and assessing control effectiveness.

Nondispersive infrared analysis also can be used to quantify many substances such as diacetyl or 2,3-pentanedione by determining the response relative to known concentrations of that substance at a selected analytical wavelength. 


\section{CONTROLLING EXPOSURES}

Controlling exposures to occupational hazards is the fundamental method of protecting workers. Traditionally, a hierarchy of controls has been used as a means of determining how to implement feasible and effective controls, which typically include: elimination, substitution, engineering controls, administrative controls and personal protective equipment (PPE). The idea behind the hierarchy of controls is that the methods at the top of the list are generally more effective in reducing the risk associated with a hazard than those at the bottom. Following the hierarchy normally leads to the implementation of inherently safer systems, ones where the risk of illness or injury has been substantially reduced.

To the extent possible, flavors should be compounded using the ingredients of lowest toxicity. For example, if a diacetyl substitute of lower toxicity that satisfies the requirements of the job is available, then this substitute should be used. Substitution of ingredients is often difficult, however, because of the many factors that determine suitability of a substitute as well as the dearth of knowledge on relative toxicity of potential substitutes. Diacetyl substitutes should not be assumed to be safe in the absence of toxicological data. The potential for workers' exposure and disease from these substitutes still remains largely unstudied.

When applied and operating properly, engineering controls can reduce airborne contaminant concentrations, thereby mitigating worker exposures. NIOSH has identified control measures including engineering controls, administrative controls, and PPE to reduce worker exposure to hazardous substances during the production of powder and liquid flavorings [NIOSH 2004, 2008a,b,c; Dunn 2007]. While much of this work emphasized the reduction of exposure to diacetyl, adoption of these control recommendations is anticipated to also reduce exposure to 2,3-pentanedione and other potentially harmful substances in the work environment. Many industries have implemented engineering controls to reduce exposure and risk of disease among their workers. Pharmaceutical companies have developed general design concepts and controls for common unit operations in manufacturing. These concepts provide a selection of approaches for working with hazardous materials including the specification of general ventilation; local exhaust ventilation (LEV); maintenance, cleaning, and disposal procedures; PPE; exposure monitoring, and; medical surveillance [Naumann et al. 1996].

The primary means for reducing exposures should be to implement process changes and engineering controls (e.g., LEV). Use of PPE should be the approach of last resort. Production processes differ among companies, so the approaches discussed below may not apply to all facilities. A sitespecific safety and health plan should be developed and should include guidance for recognizing hazardous exposures and strategies to control them. Special attention should be given to manual handling of flavoring ingredients, particularly in heated processes, and when spraying flavoring ingredients.

The food and flavoring production industries have several primary processes that may result in the potential for worker exposure to diacetyl, 2,3-pentanedione, and other flavoring ingredients. These may be grouped, from an exposure standpoint, into a few general categories including production operations, packaging operations, cleaning, and maintenance operations [ERG 2008]. Table 1 displays a list of job categories and major activities associated with these categories. For each major activity, the table indexes the figure(s) showing relevant engineering control systems. These processes include blending, mixing, and handling of flavoring ingredients in liquid and powder form. Bag emptying, bag filling, charging tanks, benchtop weighing and handling, and drum filling and emptying are a few of the production tasks of concern. The following sections discuss engineering controls that can be used to reduce workers' exposures to diacetyl, 2,3-pentanedione, and other potential airborne hazards in the primary production processes used in the food and flavoring industries. 
Table 1. Job categories and major activities of workers potentially exposed to flavorings in the food and flavor production industries, indicating relevant control information and local exhaust ventilation diagrams

\begin{tabular}{cll}
\hline Job category & \multicolumn{1}{c}{ Major activities } & See figure \\
\hline Production operator & Benchtop weighing and handling & $1,2,3$ \\
& Charging/filling tanks, mixing & $4,5,6,7,9$ \\
& Bag emptying & 10 \\
Packaging personnel & Drum filling and emptying & $7,8,9$ \\
& Bag filling & 11,12 \\
\hline
\end{tabular}

\section{ENGINEERING CONTROLS}

Many of the recommended controls observed or developed in this industry involve some type of ventilation to remove the contaminant and introduce replacement air. Some broad considerations are presented below followed by descriptions of ventilation systems for specific operations.

\section{GENERAL VENTILATION}

The use of supply and exhaust air throughout the facility can provide pressurization schemes that reduce the number of workers exposed to flavoring ingredients. Production areas should be kept at a negative pressure with respect to nearby areas. Exhaust air volume from the production area should be slightly greater than the volume of supply air. A general rule is to design the ventilation systems so that the supply flow rate is set at $5 \%-10 \%$ less than the exhaust flow rate; the difference should be at least 50 cubic feet per meter (cfm) [ACGIH 2013]. Air pressure differentials can be qualitatively checked between the production area and all neighboring areas by using an airflow visualization test. This simple test indicates whether air is flowing into or out of the production area [ACGIH 2007; Burgess et al. 2004]. Sources for airflow visualization tests (smoke tube/generator) are available from a number of commercial vendors.

\section{VENTILATION CONSIDERATIONS}

- Ensure that ventilation systems maintain the mixing or compounding rooms and other areas where flavorings are handled under negative pressure relative to the rest of the plant. This will reduce the spread of contaminants in the air of those rooms and areas to the rest of the plant.

- Ensure that air from mixing or compounding rooms is not recirculated to other areas of the facility and is exhausted directly to the outdoors. Contact the local air pollution control agency to ensure compliance with emissions requirements for new or revised engineering controls.

- Use a ventilated booth or partial enclosure to collect dusts and vapors during packaging operations. 
- Position the collection hood as close as possible to the source of the flavoring ingredients when using LEV.

- Install an indicator such as a manometer or pressure gauge fitted on the ducting near the hood inlet to provide a way to check that the device is working properly. Check the hood static pressure, face velocity and capture velocity on a periodic basis (monthly) and record the results to ensure that the system is performing as designed.

- Install a control on/off light to indicate the status of the exhaust fan.

- Place the exhaust hood opening away from doors, windows, air supply registers, and aisle ways to reduce the impact of cross drafts.

- Provide an air supply to the work area to replace most of the extracted air from LEV systems.

- Inspect hoods and enclosures for signs of damage or leaks (rust/corrosion, open access doors, etc.) and obstructions (paper, gloves, rags, etc.). Where possible, use screens to prevent foreign objects from being pulled into the system through openings (slots, hood faces, etc.).

- Discharge vented air to unoccupied areas outdoors away from doors, windows, walkways, and air inlets to prevent re-entrainment. A properly designed exhaust stack can help prevent re-entry of exhausted air into the building. Guidance on stack design is available from a variety of organizations including: American Society of Heating, Refrigerating and Air-conditioning Engineers and the American Conference of Governmental Industrial Hygienists [ACGIH 2013; ASHRAE 2011].

- Monitor workers' exposures to assess effectiveness of the system after ventilation is installed.

\section{GENERAL ENGINEERING CONSIDERATIONS}

To the extent feasible, incorporate the following elements into the engineering design.

- Use closed transfer processes to reduce worker exposure to emissions.

- Isolate the mixing area from the rest of the plant with walls, doors, or other barriers, and keep this area under negative pressure with respect to the rest of the plant to reduce dispersal of contaminants into adjacent work areas.

- Provide mechanical or pneumatic assistance with bag and sack handling.

- Place the work area away from doors, windows, and walkways to keep drafts from interfering with the ventilation and spreading contaminants.

\section{SMALL-SCALE WEIGHING AND HANDLING OF FLAVORING INGREDIENTS}

Small-scale weighing and handling of ingredients are common tasks used in flavoring production, bakeries, dairy production, and snack food manufacturing. The tasks of weighing out both dry and wet food ingredients can lead to worker exposure primarily through the scooping, pouring, and dumping of these materials. Because weighing and pouring are often performed on a benchtop workstation, the addition of slotted backdraft ventilation for both the bench and the weighing area is recommended (Figures 1 and 2). The use of engineering controls to reduce worker exposure to chemicals during mixing and weighing has been evaluated in flavoring production facilities [NIOSH 2008a,c]. In these facilities, compounders measured and poured 
flavoring ingredients on a bench and then transferred these mixtures to open tanks for liquid flavoring production or to blenders for powdered flavoring production.

Ventilated backdraft workstations used for small batch mixing have been evaluated in two field studies conducted in flavoring production plants (Figure 3) [NIOSH 2008a,c]. These stations were designed to maintain an air velocity of 100-150 feet per minute (fpm) at the face of the enclosure and reduced the exposures by $90 \%-97 \%$ when mixing tasks were performed using these stations. The selection of control velocity should be based on the material being used (powder versus liquid), plant conditions (background drafts), and momentum of contaminant source (pouring versus spraying or vigorous mixing).The use of baffles on the side and top of these workstations to better enclose the process provides improved performance and minimizes the deleterious effects of cross drafts on contaminant control. Plastic curtains can provide a reasonable enclosure and improve access to the bench area. Information on design criteria for these workstations is available from the American Conference of Governmental Industrial Hygienists and the U.K. Health and Safety Executive [ACGIH 2013; HSE 2003a].

\section{FILLING, MIXING, AND EMPTYING LARGE MIXING TANKS}

The addition of solid and liquid ingredients into tanks and other mixing vessels can cause exposure to dusts and vapors due to the displacement of air in the vessel. The use of LEV at the mixing tank helps to maintain the vessel at a negative pressure and contain evaporative emissions. Using a ventilated tank lid reduced the exposure of a worker when mixing a food flavoring by approximately $76 \%$ compared to the same operation without the ventilated tank lid (Figure 4) [NIOSH 2008c]. Ventilated tank lids have also been recommended by the U.K. Health and Safety Executive to contain vapors when mixing liquids with other liquids or solids [HSE 2003b]. Maintaining an air velocity of 100-150 fpm across the opening of the tank is recommended. A second design uses an annular exhaust slot hood to remove vapors from mixers (Figure 5) [HSE 2003c]. Another approach to controlling exposure when filling mixing vessels and tanks is to use a simple exhaust hood near the opening of fixed tanks (Figure 6); the inward velocity should be at least $200 \mathrm{fpm}$ [HSE 2003d]. A NIOSH laboratory study of different mixing tank hood designs for a 4 foot diameter tank showed that capture efficiencies above $90 \%$ were possible for all hoods and configurations at an exhaust flow rate of $200 \mathrm{cfm}$ with a crossdraft of $100 \mathrm{fpm}$ or less [Hirst et al. 2014].

The use of a ventilated mixing booth was evaluated to assess control of exposures from a large mixing tank (Figure 7). This booth allows a large portable mixing tank to be rolled inside so that chemical vapors emitted during pouring and mixing of flavoring ingredients in the tank are captured and exhausted outdoors. However, the booth can also be used for other production tasks such as large pouring and product packaging. The use of slots across the booth plenum helps to evenly distribute the flow across the height and width of the booth, and the use of side baffles/walls prevents room air drafts from reducing the effectiveness of the booth enclosure. A field study showed hood capture efficiencies of greater than $90 \%$ in tracer gas tests [NIOSH 2008a]. An average air velocity of 100-150 fpm across the face of the booth is recommended. An important design consideration is to make the booth deep enough to completely contain the process. Activities performed outside of the face of the booth will be affected by room drafts and may not be effectively controlled. Workers should be trained to always ensure that the hood is operating properly and to place the flavoring between themselves and the exhaust slots. 
After mixing is finished, the flavoring is frequently transferred into drums or other containers for shipping. Care must be taken during fluid transfer whether using gravity flow or pump discharge. The use of ventilation at the tank or barrel opening has been recommended for capture of vapors during transfer of chemicals (Figures 8 and 9) [HSE 2003e; ACGIH 2013]. For flammable liquids, suitable fans and equipment as well as appropriate grounding schemes should be used to prevent the buildup and discharge of static electricity. In all cases, when transferring flammable liquids, grounding and bonding requirements should be met to prevent sparks and explosions [NFPA 2007].

\section{DUMPING POWDERED INGREDIENTS INTO A BLENDER (BAG DUMPING)}

Manual handling of solid powders is a process used in many industries, including food and flavoring production. Opening and dumping of bags of powdered ingredients is commonly performed by workers when producing flavorings, dairy products, snack foods, and in bakeries. Typically, a worker cuts open bags of material (e.g., 50-pound bags), dumps the ingredients into a hopper, and then stacks or disposes of the empty bags. In powdered flavoring production, these hoppers are commonly outfitted onto blenders used to load the base starch ingredient for dry flavor blends. Technology used to control dusts during bag dumping has been in place for many years.

The standard control for bag dumping consists of a hopper outfitted with an LEV system to pull dusts away from workers as they open and dump bags of powdered materials. A number of commercial vendors manufacture and sell bag dumping and handling stations. The designs for these devices are available from several sources of industrial ventilation guidance. One control approach specifies a face velocity of $200 \mathrm{fpm}$ and includes a waste bag collection chute (Figure 10) [HSE 2003f]. A secondary source of exposure is handling the bags following dumping. Reentrainment of dust contamination on the surface of the bag and handling/disposal of bags typically increases worker exposure. An integral pass through to a bag disposal chute/compactor might reduce dust exposure while bag handling. Other approaches, such as spraying the inside of bags with water before compacting, may also be beneficial in reducing dust re-entrainment [Heitbrink and McKinnery 1986].

\section{DISCHARGING OF POWDERED FLAVORING FROM A BLENDER/SPRAY DRYER (BAG FILLING)}

Powder flavorings are typically mixed in industrial blenders or produced by a spray drying process. For the blending process, a powdered starch or other carbohydrate is combined with a liquid or paste flavoring agent. When the blending or spray dry process is completed, the powder product may be discharged into a bulk tote or packaged into smaller containers. The use of a ventilated collar-type hood around the discharge point can reduce workers' exposures to dust and vapors. The U.K. Health and Safety Executive has developed a control approach for filling bags with solid materials. The control specifies a ventilated enclosure around the powder discharge outlet and applies to filling smaller product bags as well as intermediate bulk containers (Figure 11) [HSE 2003g]. This design guidance recommends an air velocity of $200 \mathrm{fpm}$ into the enclosure. 
In addition to ventilation solutions, other dust control approaches have been used in a variety of industries and should be applicable for food and flavoring production. For example, an inflatable seal can be used to create a dust-tight seal on the discharge outlet of an industrial blender while the product is being unloaded. This method provides a simple technique to reduce dust escape during this process (Figure 12). Another system that could be used is the continuous liner system [Hirst et al. 2002]. In this system, the first liner is pulled down into the overpack (usually a 5-gallon bucket or a cardboard box). Product is discharged into the liner through a butterfly valve on the blender outlet. Once full, the top of the first liner sleeve is closed with tape or a fastener, or it is heat sealed and cut. The product is sealed within the poly-lined container, and a new sealed poly liner is pulled down to start discharge into the next container. This continuous process seals off the primary leak paths for dust when unloading an industrial blender or other equipment. These non-ventilation systems are commonly used in the pharmaceutical industry and may provide effective alternatives to the traditional LEV control systems.

\section{ADMINISTRATIVE AND WORK PRACTICE CONTROLS}

Engineering controls are the preferred methods for reducing occupational exposures. Administrative controls such as medical surveillance programs and work practice changes are the next steps. Safe work practices, incorporated into standard production procedures, can promote a safe and healthy workplace as well as improve efficiency and increase production.

Following are recommended administrative and work practice controls:

- Establish, implement, and maintain a medical surveillance program for all exposed employees. Medical monitoring of exposed workers can identify early work-related health effects in workers so that steps can be taken to prevent disease progression.

- Ensure workers do not eat, drink, or use tobacco products in the work area.

- Establish a hazard communication program that meets the requirements of the OSHA hazard communication standard [29 CFR 1910.1200] and the Globally Harmonized System of Classification and Labeling of Chemicals [OSHA 2006].

- Use a closed process wherever possible to transfer flavoring ingredients instead of manual pouring. When poured, liquids should be added through a funnel into a covered mixing vessel to limit spills. The work area should be kept clean and spills dealt with promptly.

- Develop procedures for assessing and maintaining ventilation systems, and document them in a written plan. Periodic monitoring of system performance may include measurement of hood static pressure and face/duct velocity as well as smoke tube testing.

- Restrict access to all areas where flavorings are being handled openly to properly protect workers (see section on PPE).

- Establish standard procedures for cleaning containers and mixing tanks. When possible, use an initial cold water rinse followed by warm water cleaning to reduce volatilization.

- Establish standard procedures for cleaning up spills small and large, wet and dry. 
- Use a vacuum with a high efficiency particulate air filter or a wet cleaning technique. Do not use compressed air and dry sweeping for cleaning, as these will re-entrain airborne particulate into the environment.

- Cover containers used to mix and store flavoring ingredients when not in use. Keep empty containers sealed as they may contain residual flavorings.

- Use cold storage for flavoring ingredients to reduce evaporation of chemicals into the air. Volatile ingredients should be added while cold to mixtures. Do not use heat when mixing flavoring ingredients.

- Wait until the pressure is at or below ambient to open pressurized vessels.

\section{PERSONAL PROTECTIVE EQUIIPMENT}

Some forms of PPE (e.g., safety glasses, gloves) are designed to prevent skin contact and exposures other than inhalation. Respirators are designed to reduce inhalation exposure but should not be used as the primary means of controlling workers' exposure to respiratory hazards for routine operations. Until risk can be assessed and compared with an occupational exposure limit, respirators should be used for exposure situations even when engineering controls are used. Workers may also need to use respirators during the implementation of engineering controls and work practices, during some short-duration maintenance and cleaning procedures, and during emergencies.

Following are recommendations regarding PPE:

- Instruct workers with potential exposure of the skin or eye to flavoring ingredients to use chemical resistant gloves and eye protection.

- Require all exposed workers to wash hands and face before eating, drinking, or smoking even in situations where gloves, face shields, and other PPE are used.

- Monitor each process to accurately determine the 8-hour time-weighted average and the short-term exposure levels of airborne diacetyl and 2,3-pentanedione to which employees may be exposed. Provide respiratory protection when potential exposures to diacetyl or 2,3-pentanedione exist.

- Establish a respiratory protection program that meets the requirements of the OSHA respiratory protection standard when respiratory protection is used [29 CFR 1910.134]. The provisions of this program include determination of tasks which require respirator use, procedures for selection, medical evaluation, fit testing, training, use, and care of respirators.

- Consider using powered air purifying respirators or supplied air respirators with a full facepiece, hood, helmet, or loose-fitting facepiece for respiratory protection against diacetyl and 2,3-pentanedione, particularly if workers are expected to wear a respirator for an extended period of time.

- Use, at a minimum, a NIOSH-certified air-purifying full facepiece respirator with organic vapor and P100 cartridge(s) or canister(s).

Additional information on the selection and use of respirators can be found in the NIOSH Respirator Selection Logic [NIOSH 2004]. 


\section{ADDITIONAL INFORMATION}

New information is continuing to evolve in regard to diacetyl and 2,3-pentanedione. Practitioners are encouraged to stay abreast of new findings through several timely websites and products including the following:

- http://www.cdc.gov/niosh/topics/flavorings

- http://www.cdc.gov/niosh/docket/archive/docket245.html

- http://www.osha.gov/SLTC/flavoringlung/index.html

- http://www.ansi.org (Z9 Standard)

- http://www.hse.gov.uk/coshh/essentials (Engineering Control Guidance)

- http://www.acgih.org (Ventilation Manual)

\section{REFERENCES}

29 CFR 1910.134. Respiratory Protection. Code of Federal Regulations. Washington, DC: U.S. Government Printing Office, Office of the Federal Register.

29 CFR 1910.1200. Guidance for hazard determination for compliance with the OSHA hazard communication standard. Code of Federal Regulations. Washington, DC: U.S. Government Printing Office, Office of the Federal Register.

Akpinar-Elci M, Travis WD, Lynch DA, Kreiss K [2004]. Bronchiolitis obliterans syndrome in popcorn plant workers. Eur Respir J 24(2):298-302.

ACGIH [2012]. 2012 TLVs $^{\oplus}$ and BEIs ${ }^{\oplus}$ : threshold limit values for chemical substances and physical agents and biological exposure indices. Cincinnati, OH: American Conference of Governmental Industrial Hygienists.

ACGIH [2013]. Industrial ventilation: a manual of recommended practice. 28th ed. Cincinnati, $\mathrm{OH}$ : American Conference of Governmental Industrial Hygienists.

ASHRAE [2011]. ASHRAE Handbook: Heating, Ventilating, and Air-conditioning Applications. Atlanta, GA: American Society of Heating, Refrigerating, and Air-Conditioning Engineers, Inc.

Boylstein R [2012]. Case study: identification of diacetyl substitutes at a microwave popcorn production plant. J Occup Environ Hyg 9:D33-34.

CDC (Centers for Disease Control and Prevention) [2007]. Fixed obstructive lung disease in the flavor-manufacturing industry-California, 2004-2007. MMWR 56(16):389-393.

Day G, LeBouf R, Grote A, Pendergrass S, Cummings K, Kreiss K, Kullman G [2011]. Identification and measurement of diacetyl substitutes in dry bakery mix production. J Occup Environ Hyg 8(2):93-103.

Department of Commerce [2004]. 2002 Economic Census Manufacturing Industry Series: Spice and extract manufacturing: 2002; Flavoring syrup and concentrate manufacturing: 2002. Washington, DC: U.S. Department of Commerce. [http://www.census.gov/prod/ec02/ ec0231i311942t.pdf]. Date accessed: March 2008.

Dunn KH [2007]. Letter of March 23, 2007, from KH Dunn, Division of Applied Research and Technology, National Institute for Occupational Safety and Health, to Kelly Howard, Department of Industrial Relations, CAL/OSHA Consultation Services. 
ERG [2008]. Technological and economic feasibility analysis for proposed OSHA standard for diacetyl and acetoin. Draft final report. Lexington, MA. By: Eastern Research Group Inc.

EPA (Environmental Protection Agency) [2002]. Non-confidential inventory updating report. [http://www.epa.gov/iur/tools/data/2002-vol.html]. Date accessed: March 2011.

Hallagan [2010]. Personal communication from John Hallagan, General Counsel Flavor Extract Manufacturers Association, based upon 2010 Industry Survey, received October 19, 2010.

Heitbrink WA, McKinnery Jr. WN [1986]. Dust control during bag opening, emptying and disposal. Appl Ind Hyg 1(2):101-109.

Hirst DVL, Dunn KH, Shulman SA, Hammond DR, Sestito N [2014]. Evaluation of engineering controls for the mixing of flavorings containing diacetyl and other volatile ingredients. J Occup Environ Hyg 11(10): 680-687.

Hirst N, Ryder M, Brocklebank M [2002]. Containment systems: a design guide. Rugby, Warwickshire, U.K.: Gulf Professional Publishing.

HSE [2003a]. Weighing and handling flour improvers etc. (craft bakery). Flour control guidance sheet FL02. In: COSHH Essentials: Easy steps to control chemicals: Control of Substances Hazardous to Health Regulations. London: U.K. Health and Safety Executive.

HSE [2003b]. Mixing liquids with other liquids or solids. Control guidance sheet 217. In: COSHH Essentials: Easy steps to control chemicals: Control of Substances Hazardous to Health Regulations. London: U.K. Health and Safety Executive.

HSE [2003c]. Mixing solids with other solids or liquids. Control guidance sheet 215. In: COSHH Essentials: Easy steps to control chemicals: Control of Substances Hazardous to Health Regulations. London: U.K. Health and Safety Executive.

HSE [2003d]. Charging reactors and mixers from a sack or keg. Control guidance sheet 210. In: COSHH Essentials: Easy steps to control chemicals: Control of Substances Hazardous to Health Regulations. London: U.K. Health and Safety Executive.

HSE [2003e]. Drum filling. Control guidance sheet 212. In: COSHH Essentials: Easy steps to control chemicals: Control of Substances Hazardous to Health Regulations. London: U.K. Health and Safety Executive.

HSE [2003f]. Sack emptying. Control guidance sheet 208. In: COSHH Essentials: Easy steps to control chemicals: Control of Substances Hazardous to Health Regulations. London: U.K. Health and Safety Executive.

HSE [2003g]. Sack filling. Control guidance sheet 206. In: COSHH Essentials: Easy steps to control chemicals: Control of Substances Hazardous to Health Regulations. London: U.K. Health and Safety Executive.

Hubbs AF, Cumpston AM, Goldsmith WT, Battelli LA, Kashon ML, Jackson MC, Frazer DG, Fedan JS, Goravanahally MP, Castranova V, Kreiss K, Willard PA, Friend S, SchweglerBerry D, Fluharty KL, Sriram K [2012]. Respiratory and olfactory cytotoxicity of inhaled 2,3pentanedione in Sprague-Dawley rats. Am J Pathol 181(3):829-844.

Hubbs AF, Moseley AE, Goldsmith WT, Jackson MC, Kashon ML, Battelli LA, Schwegler-Berry D, Goravanahally MP, Frazer D, Fedan JS, Kreiss K, Castranova V [2010]. Airway epithelial toxicity of the flavoring agent, 2,3-pentanedione. The Toxicologist CD-An official Journal of the Society of Toxicology 114(S-1):319.

Kanwal R, Kullman G, Piacitelli C, Boylstein R, Sahakian N, Martin S, Fedan K, Kreiss K [2006]. Evaluation of flavorings-related lung disease risk at six microwave popcorn plants. J Occup Environ Med 48(2):149-157. 
Kreiss K, Gomaa A, Kullman G, Fedan K, Simoes EJ, Enright PL [2002]. Clinical bronchiolitis obliterans in workers at a microwave-popcorn plant. N Engl J Med 347(5):330-338.

Lockey JE, Hilbert TJ, Levin LP, Ryan PH, White KL, Borton EK, Rice CH, McKay RT, LeMasters GK [2009]. Airway obstruction related to diacetyl exposure at microwave popcorn production facilities. Eur Respir J 34(1):63-71.

Martyny JW, Van Dyke MV, Arbuckle S, Towle M, Rose CS [2008]. Diacetyl exposures in the flavor manufacturing industry. J Occup Environ Hyg 5(11):679-688.

Morgan DL, Jokinen MP, Johnson CL, Gwinn WM, Price HC, Flake GP [2012a]. Bronchial fibrosis in rats exposed to 2,3-butanedione and 2,3-pentanedione vapors. Toxicol Sci (The Toxicologist) 126:186.

Morgan DL, Jokinen MP, Price HC, Gwinn WM, Palmer SM, Flake GP [2012b]. Bronchial and bronchiolar fibrosis in rats exposed to 2,3-pentanedione vapors: implications for bronchiolitis obliterans in humans. Toxicol Pathol 40(3):448-465. Epub 2012 Jan 3.

Morgan DL, Kirby PJ, Price HC, Bosquet RW, Taylor GJ, Gage N, Flake GP [2010]. Inhalation toxicity of acetyl proprionyl in rats and mice. Abstract 1492, The Toxicologist CD-An official Journal of the Society of Toxicology, Volume 114, Number S-1, March 2010.

Naumann BD, Sargent EV, Starkman BS, Fraser WJ, Becker GT, Kirk GD [1996]. Performancebased exposure control limits for pharmaceutical active ingredients. AIHA J 57(1):33-42.

NFPA [2007]. NFPA 77: Recommended Practice on Static Electricity. Quincy, MA: National Fire Protection Association.

NIOSH [2004a]. NIOSH alert: preventing lung disease in workers who use or make flavorings. U.S. Department of Health and Human Services, Centers for Disease Control and Prevention, National Institute for Occupational Safety and Health. DHHS (NIOSH) Publication No. 2004-110.

NIOSH [2004b]. NIOSH Respirator Selection Logic. By Bollinger N. Cincinnati, OH: U.S. Department of Health and Human Services, Centers for Disease Control and Prevention, National Institute for Occupational Safety and Health, DHHS (NIOSH) Publication No. 2005-100.

NIOSH [2008a]. In-depth survey report: evaluation of engineering controls for the mixing of flavoring chemicals at Gold Coast Ingredients, Inc. Commerce, CA. Cincinnati, OH: U.S. Department of Health and Human Services, Centers for Disease Control and Prevention, National Institute for Occupational Safety and Health. Survey Report No. EPHB 322-11a.

NIOSH [2008b]. Hazard evaluation and technical assistance report: Evaluating occupational exposures and work practices at Gold Coast Ingredients, Inc. Technical Assistance Report to CAL-OSHA. Cincinnati, OH: U.S. Department of Health and Human Services, Centers for Disease Control and Prevention, National Institute for Occupational Safety and Health, NIOSH HETA Report No. 2006-0361-1.

NIOSH [2008c]. In-depth survey report: evaluation of engineering controls for the production of liquid and powder flavoring chemicals at Kerry Ingredients and Flavours, Inc. formerly Mastertaste, Inc., Commerce, CA. DHHS (NIOSH) Publication No. EPHB 322-12a.

NIOSH [2011a]. Hazard evaluation and technical assistance report: Lung function (spirometry) testing in employees at a flavorings manufacturing plant-Indiana. Cincinnati, OH: U.S. Department of Health and Human Services, Centers for Disease Control and Prevention, National Institute for Occupational Safety and Health, NIOSH HETA Report No. 20080155-3131.

NIOSH [2011b]. Draft criteria for a recommended standard: occupational exposure to diacetyl and 2,3-pentanedione. U.S. Department of Health and Human Services, Centers for Disease 
Control and Prevention, National Institute for Occupational Safety and Health. DHHS (NIOSH) Publication No. 2011-XXX. [http://www.cdc.gov/niosh/docket/archive/pdfs/ NIOSH-245/0245-081211-draftdocument.pdf].

NIOSH [2012]. NIOSH manual of analytical methods (NMAM ${ }^{\circledR}$ ). 4th ed. Schlecht PC, O'Connor PF, eds. Cincinnati, OH: U.S. Department of Health and Human Services, Centers for Disease Control and Prevention, National Institute for Occupational Safety and Health, DHHS (NIOSH) Publication 94-113 (August 1994); 1st Supplement Publication 96-135, 2nd Supplement Publication 98-119; 3rd Supplement 2003-154.

OSHA [2006]. A Guide to The Globally Harmonized System of Classification and Labeling of Chemicals (GHS). Washington, DC: U.S. Department of Labor, Occupational Safety and Health Administration. [https://www.osha.gov/dsg/hazcom/ghs.html]. Date accessed: August 2013.

OSHA [2008a]. OSHA technical manual. Section II: Sampling, measurement methods and instruments. Washington, DC: U.S. Department of Labor, Occupational Safety and Health Administration. [http://www.osha.gov/dts/osta/otm/otm_ii/otm_ii_1.html]. Date accessed: June 2013.

OSHA [2008b]. OSHA sampling and analytical methods. Hendricks W, ed. Salt Lake City, UT: U.S. Department of Labor, Occupational Safety and Health Administration. Acetoin/ Diacetyl 1013. [http://www.osha.gov/dts/sltc/methods/validated/1013/1013.html]. Date accessed: June 2009.

OSHA [2008c]. OSHA sampling and analytical methods. Hendricks W, ed. Salt Lake City, UT: U.S. Department of Labor, Occupational Safety and Health Administration. Acetoin/ Diacetyl 1012. [http://www.osha.gov/dts/sltc/methods/validated/1012/1012.html]. Date accessed: June 2009.

OSHA [2010]. OSHA sampling and analytical methods. Hendricks W, ed. Salt Lake City, UT: U.S. Department of Labor, Occupational Safety and Health Administration. 2,3-Pentanedione 1016. [http://www.osha.gov/dts/sltc/methods/validated/1016/1016.pdf]. Date accessed: March 2011. 
This page intentionally left blank 


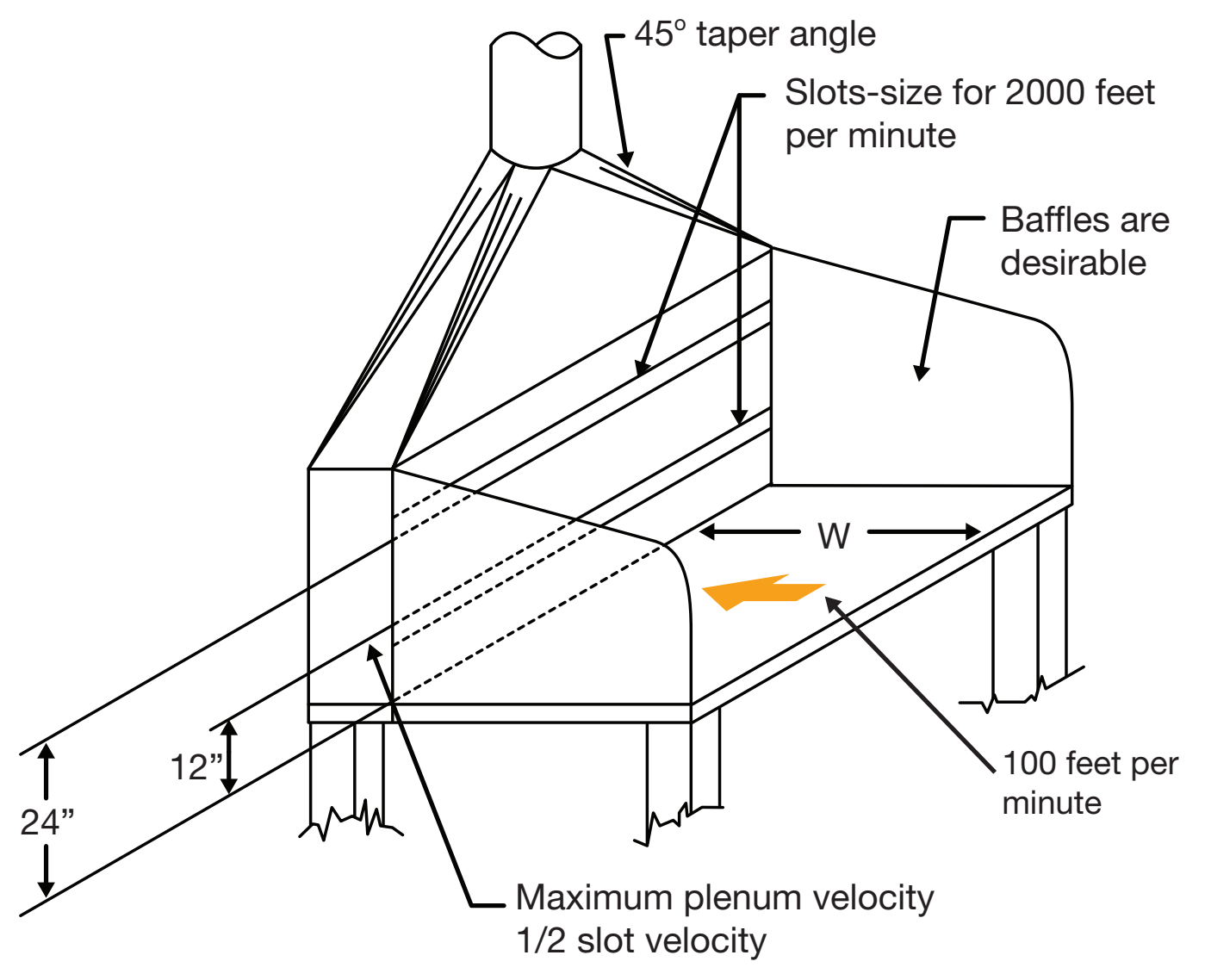

*VS-90-01, From ACGIH, Industrial Ventilation: A Manual of Recommended Practice for Design, 27th Edition. Copyright 2010. Reprinted with permission. 


\section{FIGURE 2*}

\section{Benchtop ventilation for weighing/handling powders}

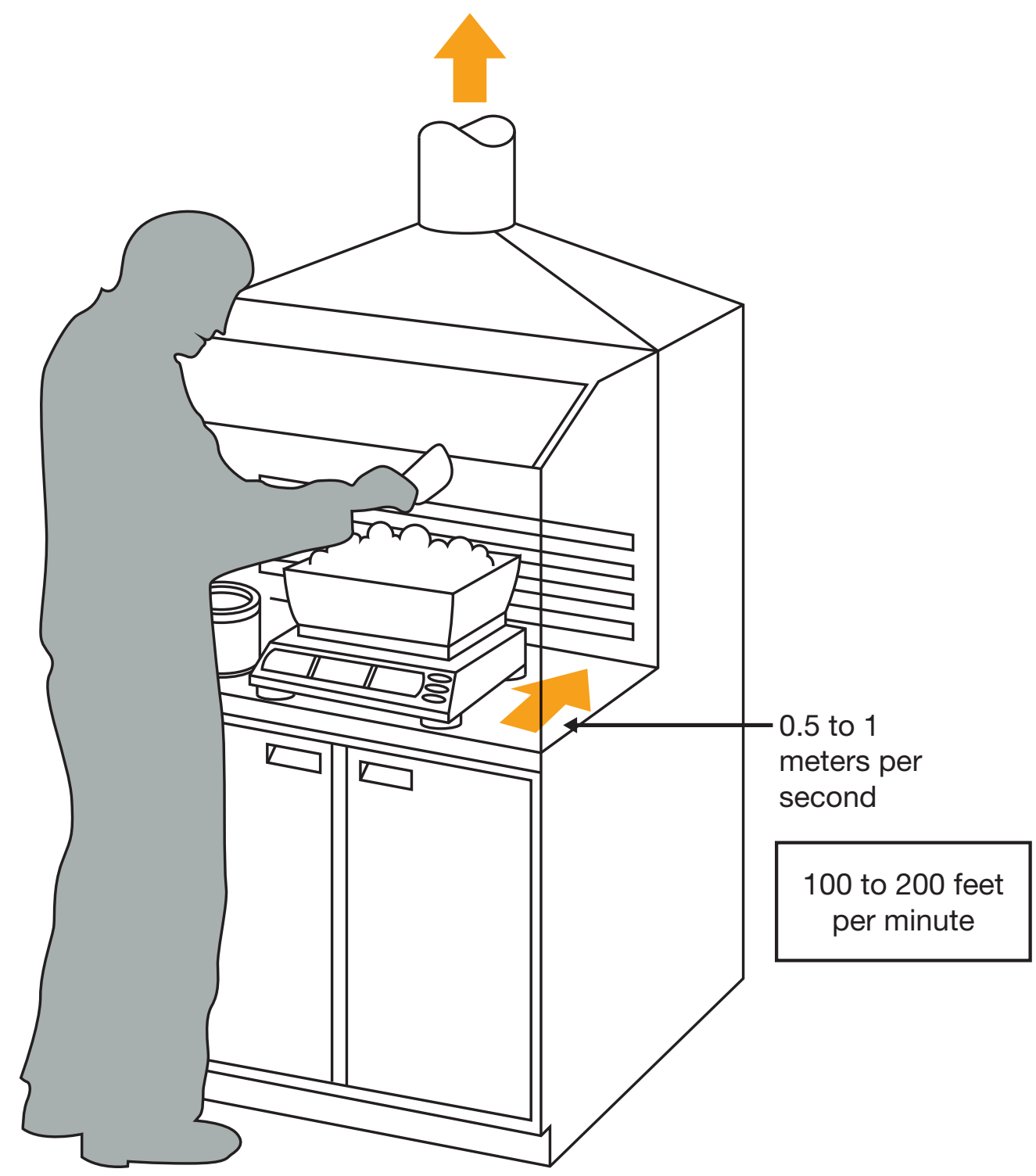

${ }^{\star}$ Contains public sector information published by the Health and Safety Executive and licensed under the Open Government License v1.0. 
FIGURE 3

Ventilated small batch mixing workstation
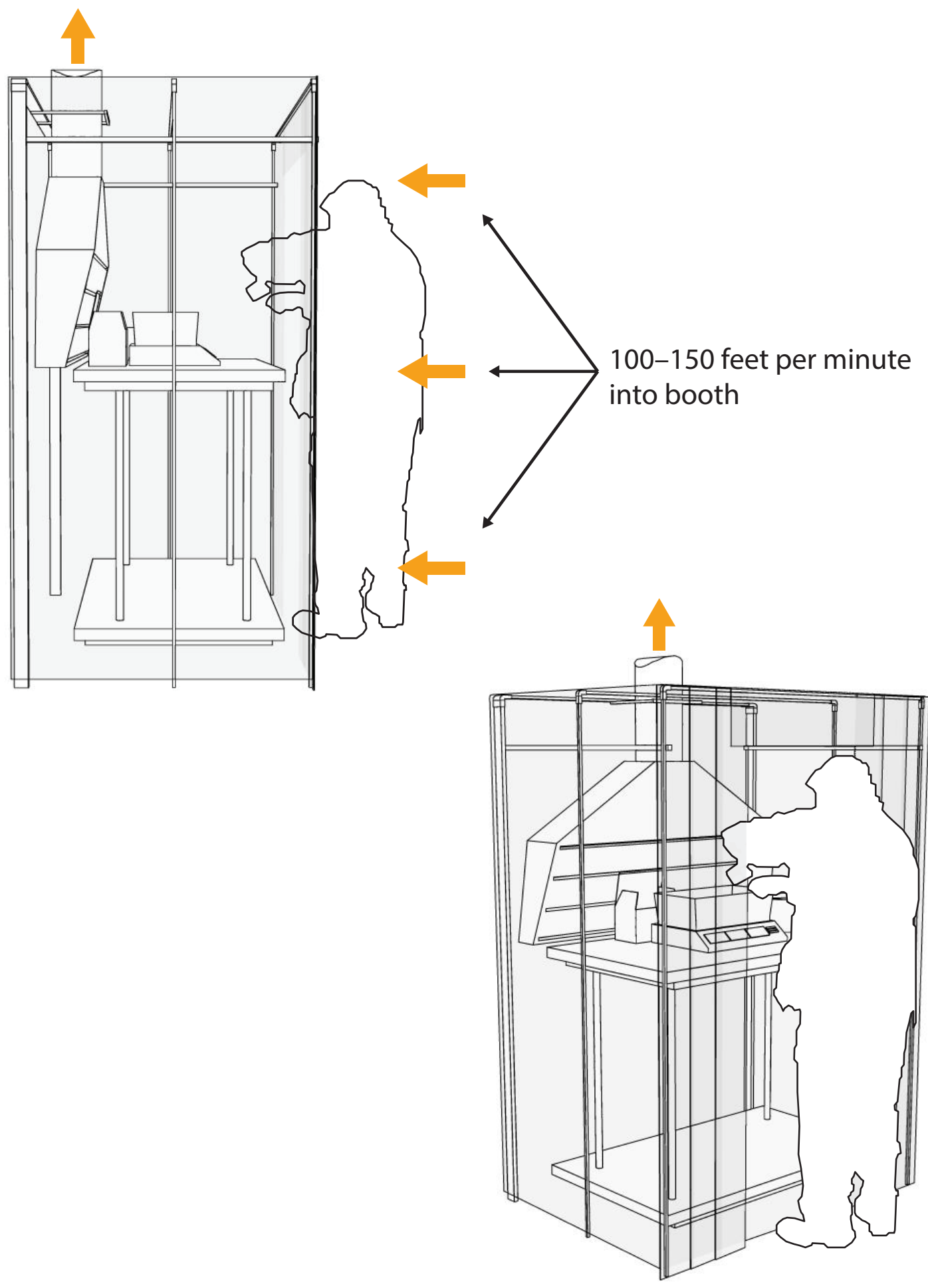


\section{FIGURE 4}

Mixing vessel with a ventilated hinged tank lid

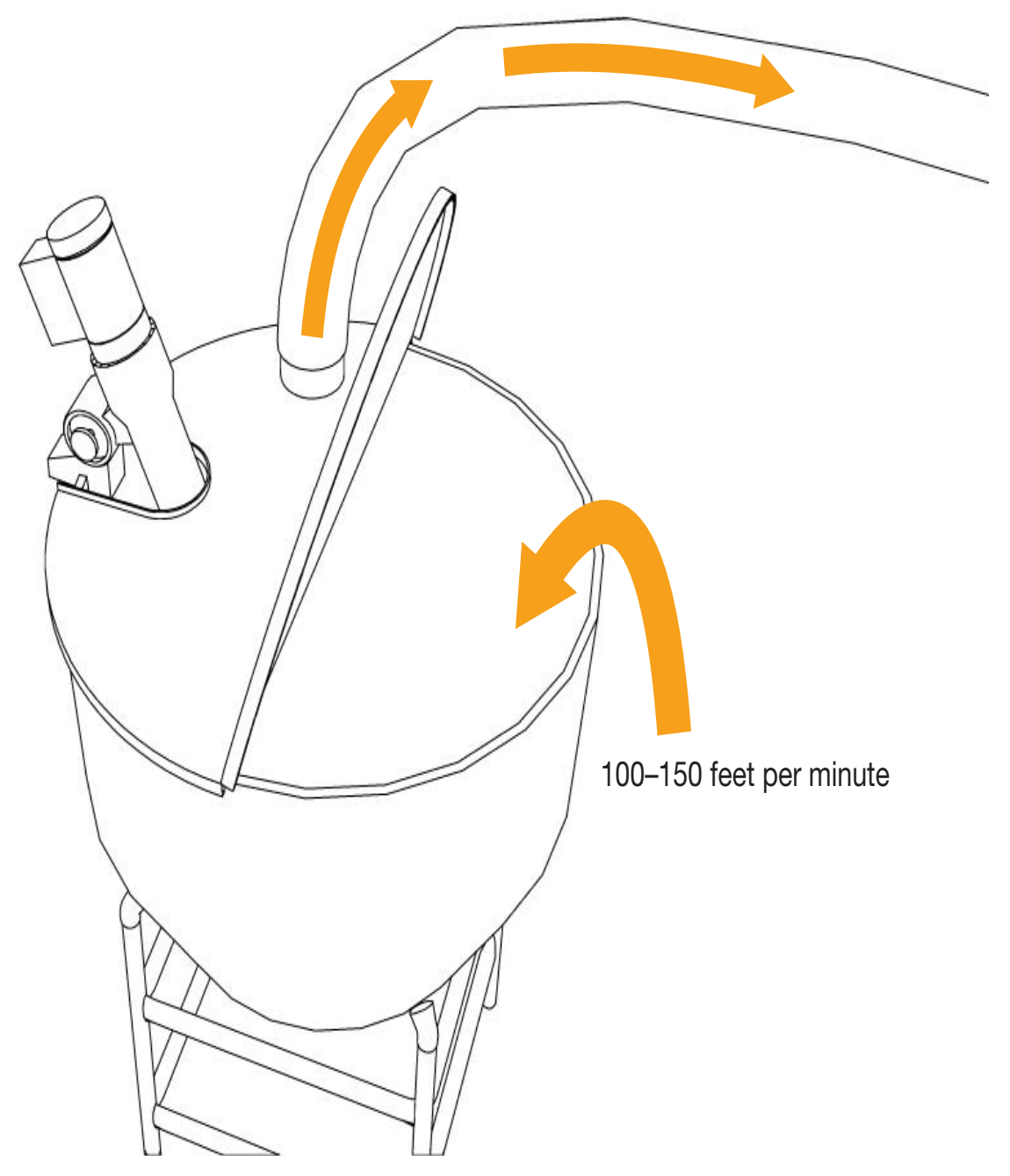




\section{FIGURE $5 *$}

Annular exhaust for capturing vapors from mixers

Exhaust

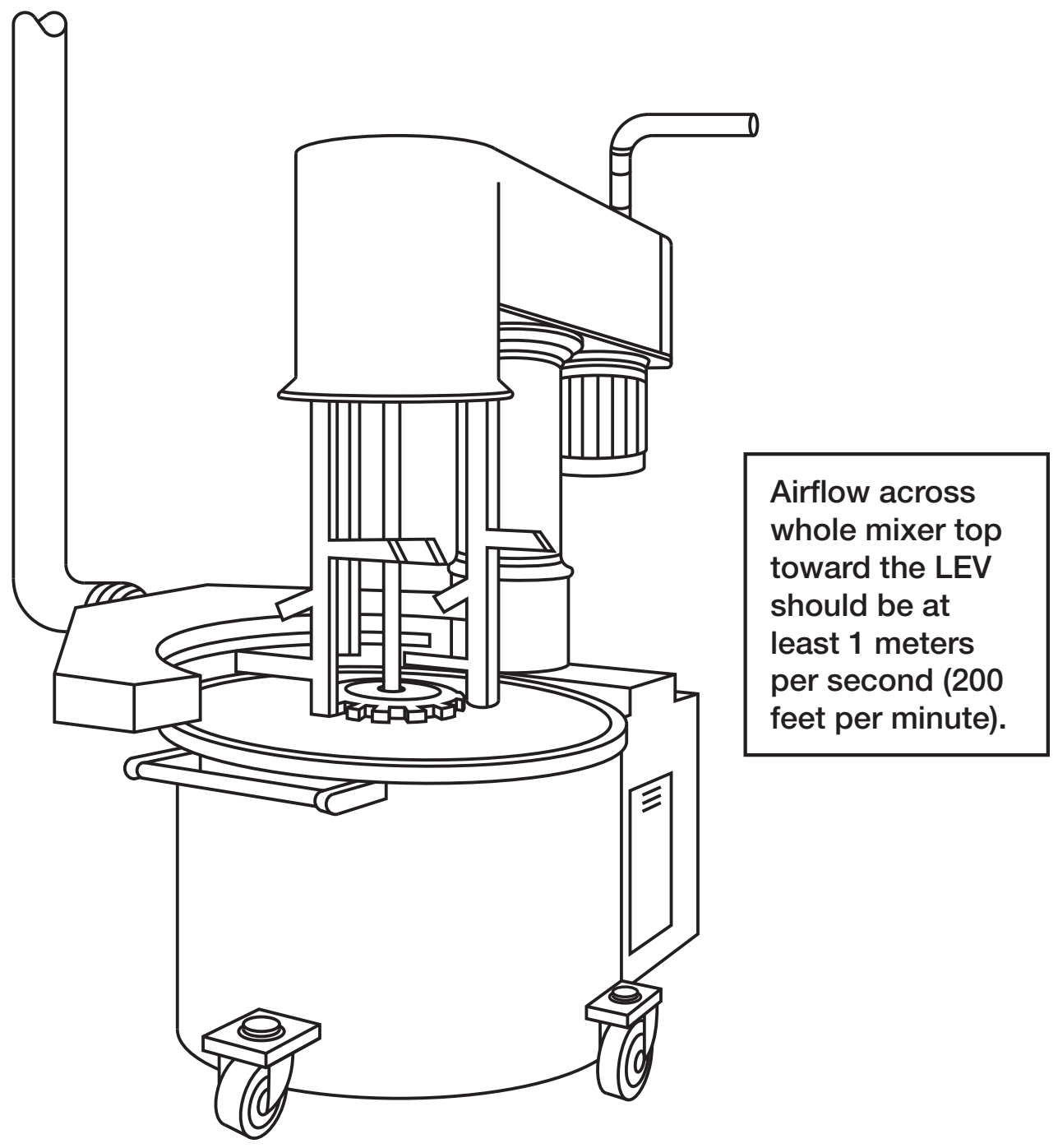

${ }^{\star}$ Contains public sector information published by the Health and Safety Executive and licensed under the Open Government License v1.0. 


\section{FIGURE 6*}

Charging reactors and mixers from a sack or keg

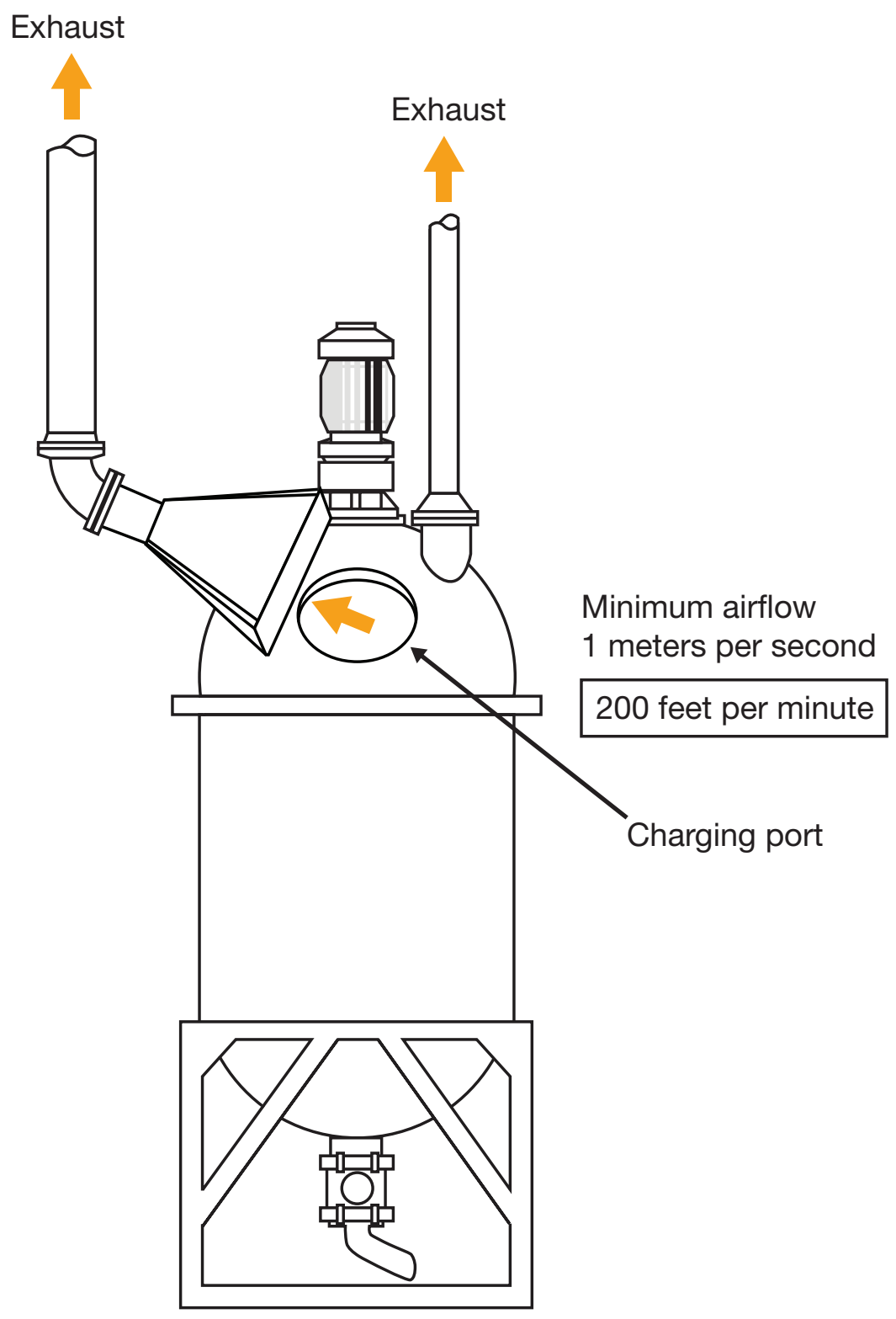

${ }^{\star}$ Contains public sector information published by the Health and Safety Executive and licensed under the Open Government License v1.0. 


\section{FIGURE 7}

\section{Ventilated booth for large batch mixing}
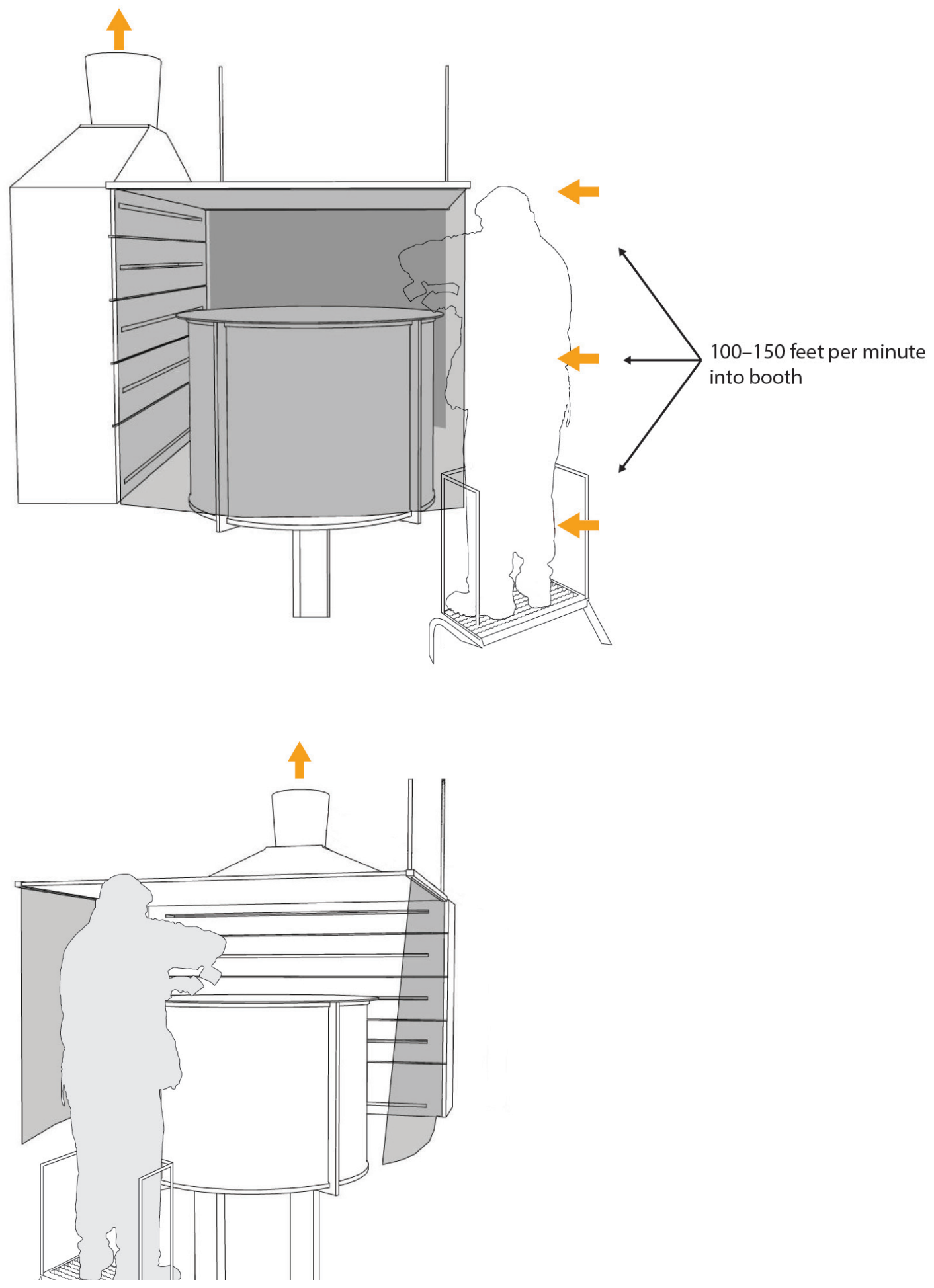


\section{FIGURE 8*}

Annular exhaust for capturing vapors during drum filling

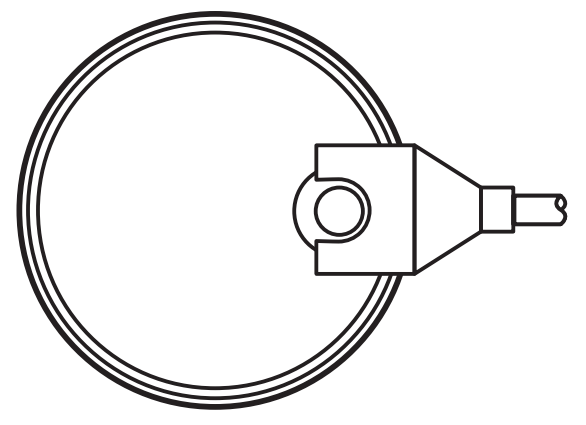

OVERHEAD VIEW

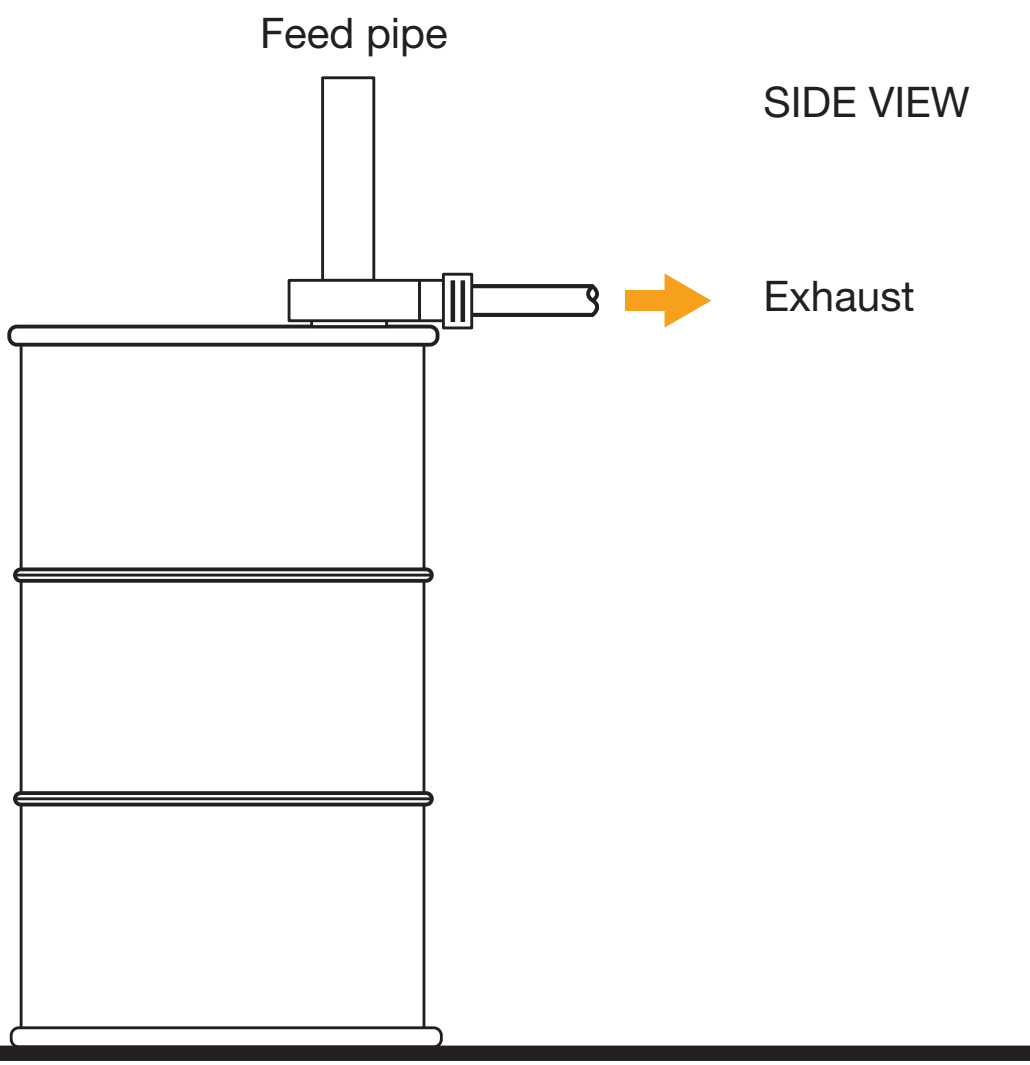

Airflow across drum cap should be at least 0.5 meters per second (100 feet per minute) capture.

${ }^{\star}$ Contains public sector information published by the Health and Safety Executive and licensed under the Open Government License v1.0. 


\section{FIGURE $9^{*}$}

\section{Ventilation design options for capturing vapors during drum filling}

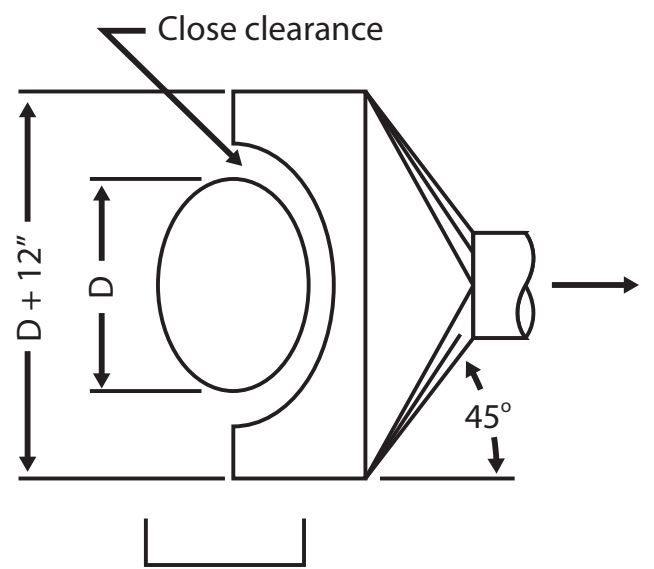

$\mathrm{Q}=100 \mathrm{cfm} / \mathrm{ft}^{2}$ barrel top (minimum)

Minimum duct velocity $=3500 \mathrm{fpm}$

$h_{e}=1.78 \mathrm{VP}_{\mathrm{s}}+0.25 \mathrm{VP}_{\mathrm{d}}$

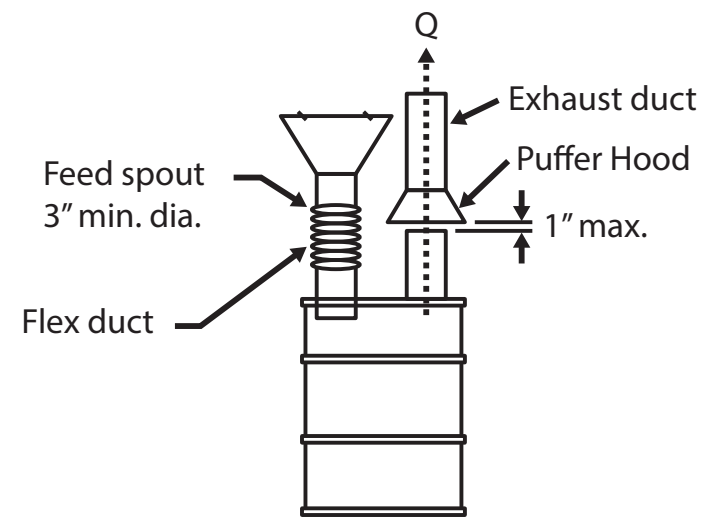

$\mathrm{Q}=50 \mathrm{cfm} \times$ drum diam. $(\mathrm{ft})$

Minimum duct velocity $=3500 \mathrm{fpm}$

$\mathrm{h}_{\mathrm{e}}=0.25 \mathrm{VP}_{\mathrm{d}}$

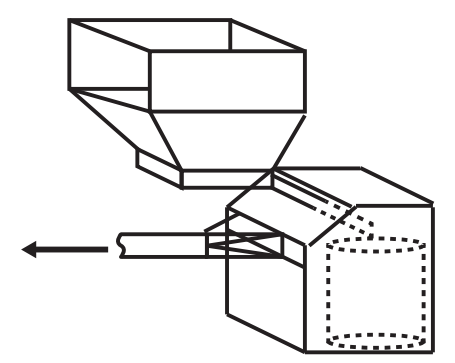

$\mathrm{Q}=150 \mathrm{cfm} / \mathrm{ft}^{2}$ of open face area Minimum duct velocity $=3500 \mathrm{fpm}$ $\mathrm{h}_{\mathrm{e}}=0.25 \mathrm{VP}_{\mathrm{d}}\left(45^{\circ}\right.$ taper $)$

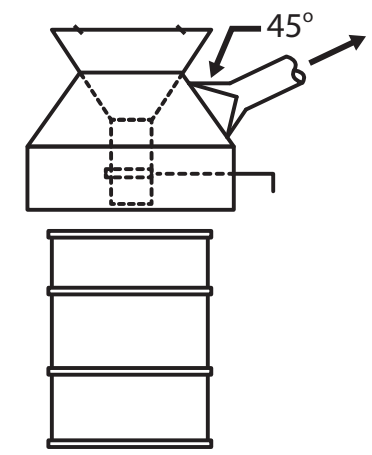

$\mathrm{Q}=300-400 \mathrm{cfm}$

Minimum duct velocity $=3500 \mathrm{fpm}$

$\mathrm{h}_{\mathrm{e}}=0.25 \mathrm{VP}_{\mathrm{d}}$

Note 1: Air displaced by material feed rate may require higher exhaust flow rates.

Note 2: Excessive airflow can cause loss of product.

Note 3: When transferring flammable or combustible liquids, bonding and grounding requirements of NFPA Code 77 should be followed.

*VS-15-01, From ACGIH, Industrial Ventilation: A Manual of Recommended Practice for Design, 27th Edition. Copyright 2010. Reprinted with permission. 


\section{FIGURE $10^{*}$}

\section{Ventilated bag dumping/emptying station}

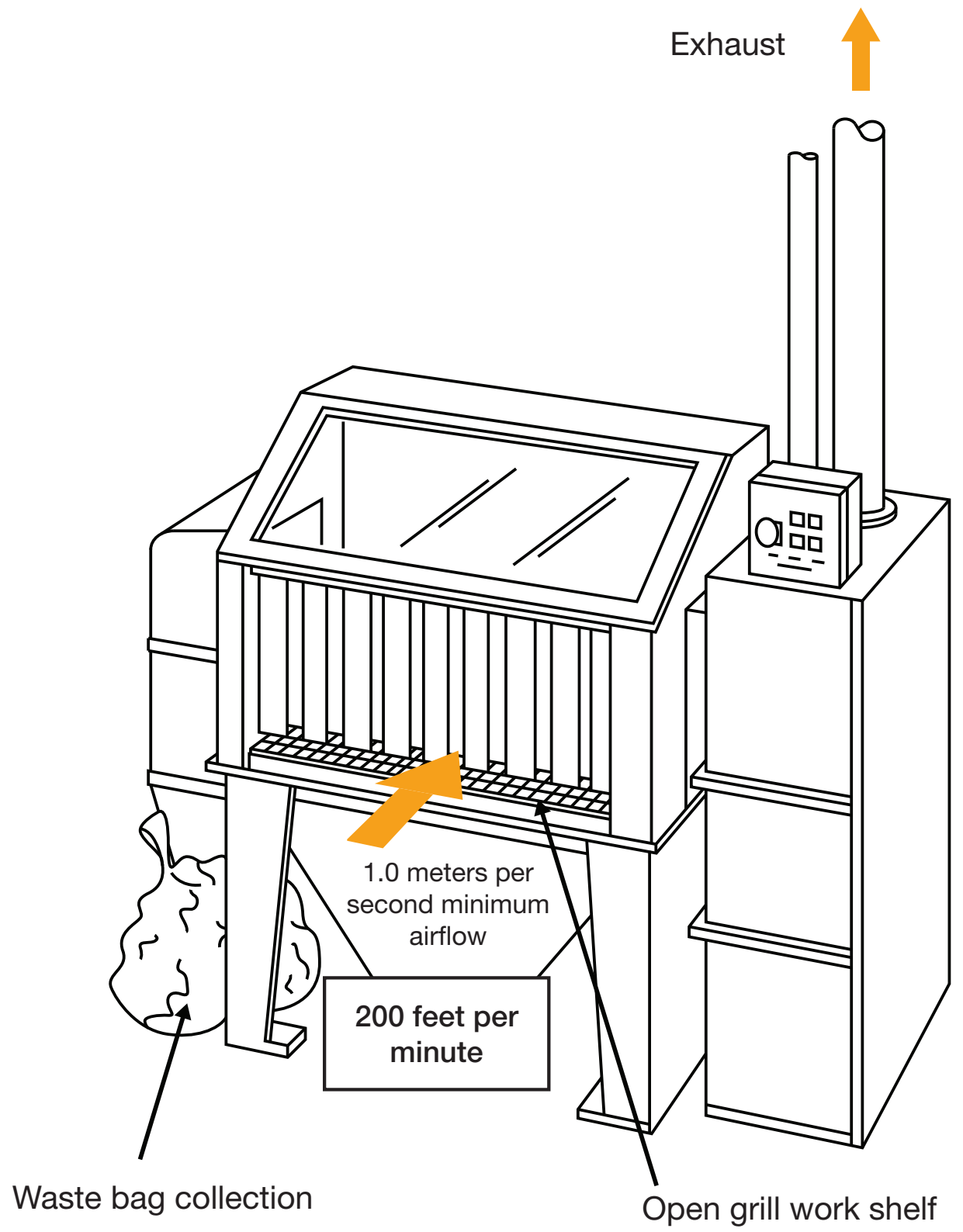

${ }^{\star}$ Contains public sector information published by the Health and Safety Executive and licensed under the Open Government License v1.0. 


\section{FIGURE $11^{*}$}

Ventilation for bag filling

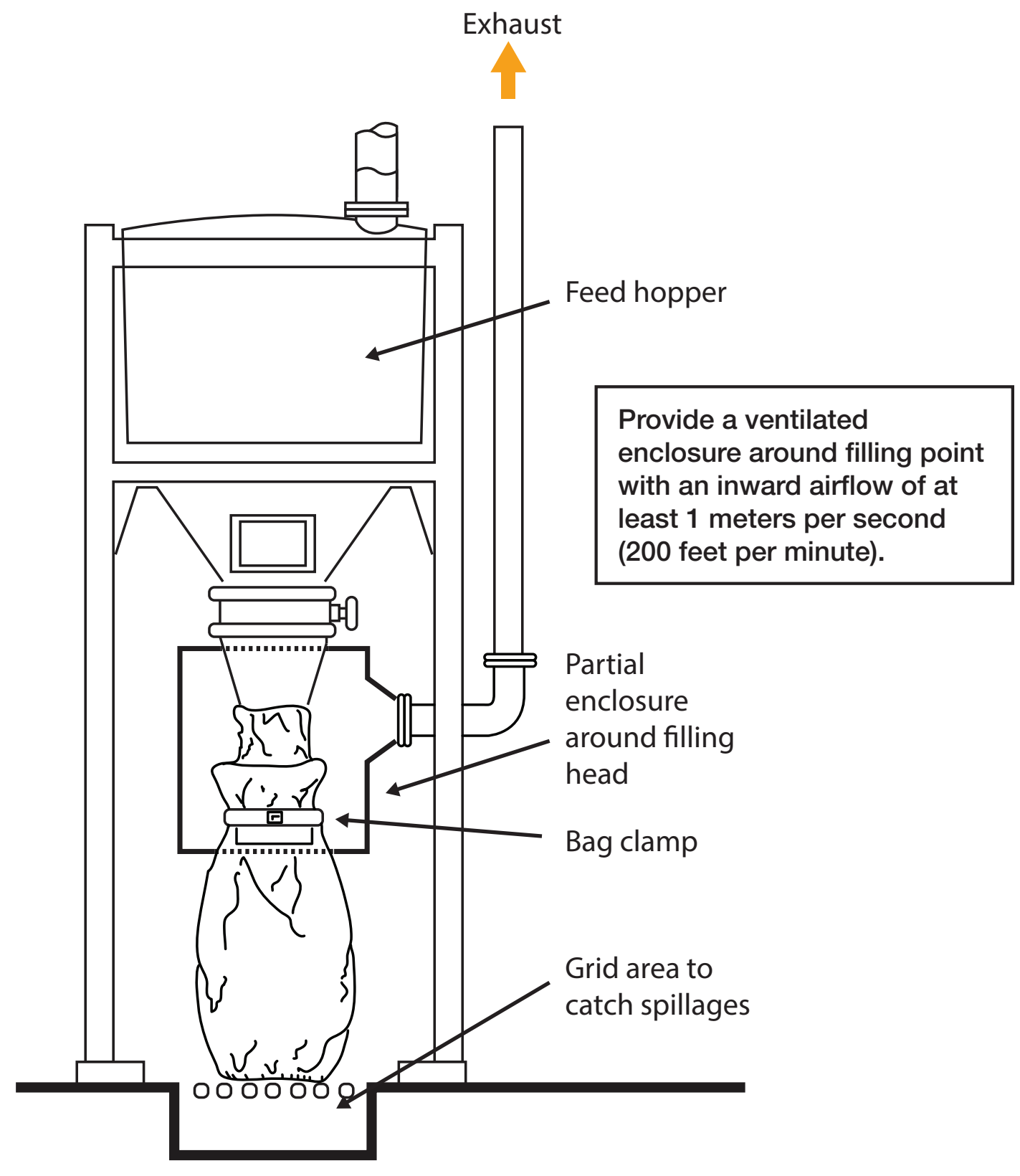

${ }^{\star}$ Contains public sector information published by the Health and Safety Executive and licensed under the Open Government License v1.0. 


\section{FIGURE 12}

Dust control during bag filling operation

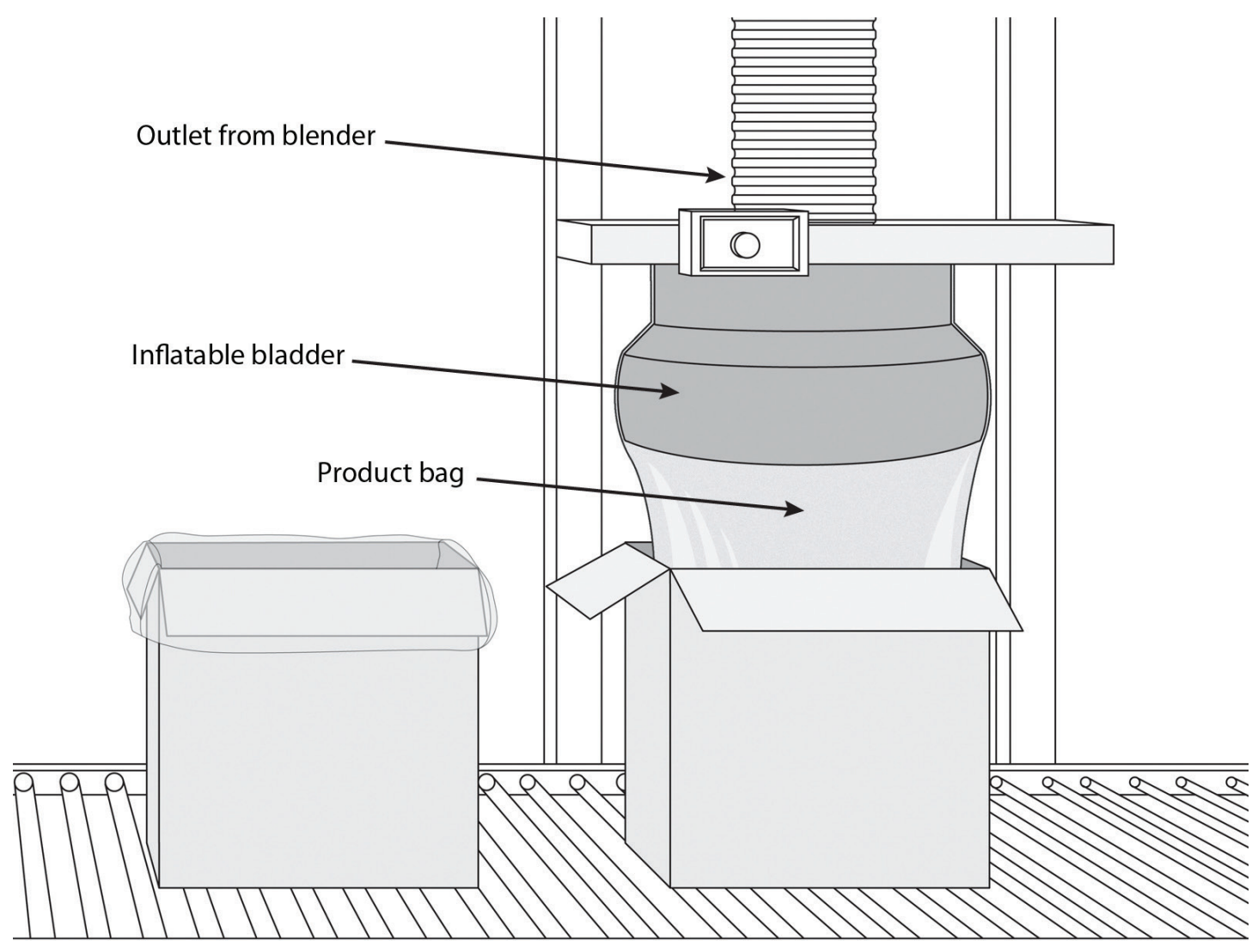


This document is in the public domain and may be freely copied or reprinted. NIOSH encourages all readers of the Best Practices documents to make them available to all interested employers and workers.

As part of the Centers for Disease Control and Prevention, NIOSH is the federal agency responsible for conducting research and making recommendations to prevent work-related illness and injuries. Best Practices documents are based on research studies that show how worker exposures to hazardous agents or activities can be significantly reduced. 
This page intentionally left blank 
This page intentionally left blank 


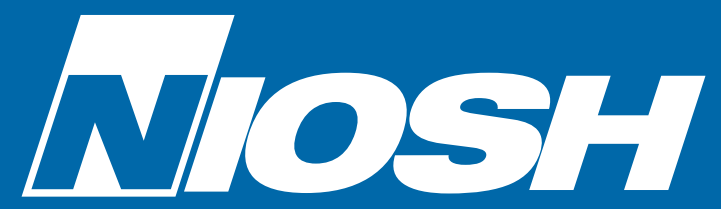

Delivering on the Nation's promise: safety and health at work for all people through research and prevention

To receive NIOSH documents or more information about occupational safety and health topics, contact NIOSH at

1-800-CDC-INFO (1-800-232-4636)

TTY: 1-888-232-6348

CDC INFO: www.cdc.gov/info

or visit the NIOSH website at www.cdc.gov/niosh.

For a monthly update on news at NIOSH, subscribe to NIOSH eNews by visiting www.cdc.gov/niosh/eNews.

DHHS (NIOSH) Publication No. 2015-197

SAFER • HEALTHIER • PEOPLETM 